\title{
Identifying Grade 8 and 9 Technology Teachers' Areas of Need for Intervention in Limpopo Province
}

\author{
T.A. Mapotse ${ }^{1}$ and M.T. Gumbo ${ }^{2}$ \\ ${ }^{1}$ University of South Africa, College of Education, 7-8 AJH van der Walt Building, \\ PO Box 392, UNISA 0003, South Africa \\ E-mail:mapotta@unisa.ac.za \\ ${ }^{2}$ University of South Africa, College of Education, 6-19 AJH van der Walt Building, \\ PO Box 392, UNISA 0003, South Africa \\ E-mail:gumbomt@unisa.ac.za
}

KEYWORDS Technology Education. Action Research. Reconnaissance Study. Critical Theory. Challenges

\begin{abstract}
The aim of this article is to report the findings on the gaps that were identified in the teaching of technology by Grade 8 and 9 teachers at Mankweng Circuit of Limpopo Province. This was done so that appropriate action research-based intervention strategies could be embarked upon to fill these gaps. A reconnaissance or preliminary study as the first cycle stage of action research was instrumental in identifying these gaps. Observation, interviews and a questionnaire were employed in gathering data from the teachers from five sampled secondary schools. The findings revealed issues that have to do with technology teachers' ability and capacity (knowledge on lesson planning, assessment, interpretation of curriculum policy and its implementation, resources) and those beyond teacher' control (teaching experience, level of internal and external support, resources, teacher-learner ratio). Identifying these gaps will help inform technology teacher practice about aspects of incapacity and intervention to be considered.
\end{abstract}

\section{INTRODUCTION}

Since its introduction in the South African school curriculum and thus its implementation, the technology education subject has raised a number of interesting issues, not the least of which is a conceptual understanding of technology (Shafër 1999). Rauscher (2010) concurs that the advent of technology education, nationally and internationally, has posed challenges different from those experienced in regard to other learning areas. Amongst the multiple challenges that can be mentioned, teacher development and empowerment becomes prominent as it is technology teachers that are placed at the forefront to teach learners this relatively new subject. These are teachers lumped with the rest of other teachers when it comes to teacher training, whose situation was even as early as the rolling out of the outcomes-based Curriculum 2005 in 1998, made complex by the new demands posed by the new curriculum itself. The majority of teachers already teaching technology in schools found this initial change to outcomesbased education (OBE) and the introduction of Curriculum 2005 (C2005) to be very complicated, confusing and demoralising with lots of new terminology and content to be learned (De Jager 2011). To try to make the curriculum understand- able, more changes followed in 2002 after the review of C2005 in 2000. The reviewed C2005 was renamed National Curriculum Statement (NCS). This review was followed by yet another review in 2009 and in 2010 the curriculum was implemented as planned. This review produced the Curriculum and Assessment Policy Statement (CAPS). CAPS is about the revised policy implementation strategy to try and address the constraints that C2005 to NCS posed (De Jager 2011). This confirms the challenge that teachers face regarding their understanding of the curriculum; expressed in terms of constraints that they face about its implementation. Specifically, technology is an area that needs skilled teachers due to its nature particularly as a theory-practice based subject. However, it is distressing to disclose that $99 \%$ of the teachers teaching technology are not qualified to teach technology (Nkosi 2008; Lovington 2009). The situation seems worse in Limpopo Province, which is among provinces known to be underperforming. The researchers therefore chose one circuit in this province to conduct this study.

How they go about presenting this report is first to frame the study within the critical theoretical perspective and its application in the study. Second, they discuss our becoming aware of the problem and our assumptions about it. 
They proceed by explaining the research design and finally present our findings.

\section{Critical Theoretical Framework}

Theory helps the researcher by grounding the study within the existing literature and directing the researcher to make proper research decisions and sense of the world around. Theory is also an explanation that discusses how a phenomenon operates and why it operates as it does and it serves the purpose of making sense out of current knowledge by integrating and summarizing this knowledge, and thus it can be used to guide research by making predictions (Christensen and Johnson 2004).

The importance of a theoretical framework or a thorough literature study at the beginning of scale development was identified in 1952 by Goode and Hatt (cited in De Vos et al. 2002) where they stated that the researcher should first have a thorough knowledge of the subject regardless of the data gathering technique employed. The researcher should systematically exploit both that technique and those of others through a careful study of literature. Critical theory was first defined by Max Horkheimer of the Frankfurt School of sociology in his 1937 essay Traditional and critical theory (Tooley 2000). The effort to conceptualize critical theory relied on the writings of Karl Marx (Tooley 2000). Its basic purpose was emancipation and self-determination.

The researchers' choice of critical theory was motivated by their intent to emancipate the technology teachers in terms of overcoming the challenges that they faced in their knowledge and teaching of the subject. In the absence of praxis its positioning cannot be validated. By reflecting critically on their unfavourable status-quo, technology teachers could be helped to think about how they could free themselves from such unfavourable conditions and take action about it - so as to be emancipated. In this way they could overcome their obstacle (Williamson 2013), understood here as their challenges or barriers (Watson and Watson 2011) and envision viable alternatives ways (Williamson 2013), that is, to improve their situation. The kind of intervention in such involvement is facilitative rather than instructive, so that those being helped can later be self-reliant and become independent to address their situation. Specifically, the next section explains how critical theory found relevance in this study.

\section{The Value and Application of Critical Theory in this Study}

In the context of this study, critical theory is about changing technology teachers' challenges (deemed as oppressive to their practice) stated in the abstract above into workable ways so they can teach technology amidst the circumstances that they face. This study will hopefully create enough awareness in these teachers to be able to pass judgment on their practice of technology and to evaluate their knowledge base of technology with the sole purpose of being emancipated from this situation. Thus, for purposes of this study, critical theory was used to exploit the literature in the field of technology education (Creswell 1994).

Critical theory indicates that there is a fundamental dialectical relationship and that theory and practice are indivisible (Tooley 2000), especially in technology. This aligns well with our understanding of technology education, that it is fundamentally a hands-on enterprise. Handson in technology must be taken to refer to learning through experiences, that is, through practical engagement in investigating, designing, making, evaluating and communicating ideas and plans (Department of Education 2004). Approaching it theoretically is unfathomable.

Technology education's core content and themes stress that the outcome should be a product, artifact, model, ornament, or new systems or processes. Applied in this study, we expected that from a critical theoretical perspective, the ultimate action research intervention would emancipate the Grades 8 and 9 technology teachers in selected schools of the Limpopo Province from their challenges as stated above. Hence, we assumed that engaging teachers in critical theory had the potential to improve their understanding of the knowledge and pedagogy of technology within their context.

The next section explains how the researchers became aware of the problem.

\section{Becoming Aware of the Problem}

One of the researchers (first author) became aware of the problem as a lecturer at the University of Limpopo before he joined Unisa. He taught pre-service student teachers enrolled for the Bachelor of Education in Technology Education. During the evaluation of the student 
teachers' practice teaching he observed a lack of knowledge in the teaching of technology by veteran teachers. This lack of knowledge manifested in:

- The analysis and interpretation of the technology curriculum policy document: The assigned mentor teachers to the pre-service student teachers did not have any technology curriculum policy document which serves as a guide about what to teach. This suggested that teachers saw the curriculum policy document as monstrous and would rather not bother with it but stick to their traditional pedagogical strategies. It was hard to believe that mentor teachers did not have technology curriculum policy document even though it could be easily obtained from the Department of Education or accessed on the Department of Education's website.

- Planning of the learning programme, work schedule and lesson: There was no phase or grade joint planning as teachers were teaching different topics within a term. Learners wrote tests on different topics. This was cumbersome for the student teachers as they had to prepare different lessons for the same grades. Student teachers were to receive work schedule from their mentor teachers for record purposes in their teaching practice portfolios and for use during teaching. However, they claimed that they did not get any work schedules from their mentors.

- Absence of creativity in utilizing the material resources available in the local context: Learners were without any textbooks. They relied only on their teachers. There was no display of any technology posters or projects made by technology learners. Veteran teachers did not attempt any projects with learners, making the excuse that they did not have any resources, until the University of Limpopo student teachers came for their practice teaching. Student teachers engaged both their mentor teachers and learners in utilizing the material resources available in their localities.

Student teachers seemed more knowledgeable in their subject of technology compared to their assigned mentor teachers. They ended up exchanging roles with their mentors to mentor them (mentors) because their situation posed such demand. This intervention confirms Department of Education's (2003) declaration:

"Whilst educators in South African schools are qualified to teach a variety of subjects, many of the educators of technology are uncomfortable with the pedagogy of technology".

The situation about the challenges that teachers face can also be understood in terms of the general picture about teacher training in Limpopo Province. Pretorius (2004) writes in this regard that about 10000 of Limpopo Province's 54298 teachers are under-qualified. Bearing in mind Department of Education Gauteng's Memorandum 202 as cited above about the national picture, the need for an urgent intervention is even greater. Nkosi (2008) conducted a study in Mpumalanga concentrating only on Grade 7 technology teachers where she used the technological process as a framework for the improvement of technology instruction. It is interesting as well to note that Letsoalo (2007) embarked on a study in Mpumalanga-Thulamahashe Circuit with Grade 9 technology learners to develop an instrument to monitor the technological process during the making of a technological product. This study attempts to emancipate teachers in the teaching of technology by addressing the identified areas above and/or those that teachers presented during the action research inquiry (reconnaissance study) as will be explained later.

The researchers argue that teachers can implement technology with confidence and every chance of success within their context only if they can be guided how. The starting point is to identify the areas of their need. That is what this study, which the researchers decided to call a preliminary or reconnaissance study, seeks to do. It is preliminary because it is part of a more comprehensive or main action research project that would be implemented to address the needy areas the need areas as identified and confirmed. The researchers thus address the question:

What areas of need can be identified through preliminary action research for intervention in the teaching of Grade 8 and 9 technology in Limpopo Province?

\section{Our Own Assumptions and Claims about the Problem}

Researchers usually enter a research project with certain claims and assumptions. Assump- 
tions are any important facts presumed to be true but not yet verified empirically (Gay 1987; Mauer 1996). The researchers embarked on this study holding the following assumptions and their antecedent claims informed by the situation and problem that they identified regarding the teaching of technology:

- Assumption 1: After Technology Education (TE) was introduced in the South African school curriculum more than a decade ago, TE teachers are still grappling with its knowledge and pedagogy.

- Claim 1: Many technology teachers teach technology without the appropriate technology qualifications or prior knowledge of the subject.

- Assumption 2: Action Research (AR) processes with technology teachers will empower them with the necessary technological content knowledge and pedagogy.

- Claim 2: Sessions with technology teachers guided by the AR intervention strategies are likely going to will empower them in terms of knowledge and pedagogies.

Our assumptions and claims are supported by Reddy (2001) who maintains that no established tradition of TE teaching and learning exists in the country and that this is likely to pose major problems not only to TE teachers but to Department of Education at large. Pudi (2007) also observes that the implementation of TE has been a hurdle for both teachers and learners. There is a generally low capacity in TE teachers' content knowledge, cognitive and manual skills. This, coupled with the low morale of some teachers resulting from curriculum transmutation, part of which was an attempt to do away with technology (Chisholm et al. 2000; Department of Education 2001) has exacerbated the teaching related problems that the TE teachers experience. The researchers thus believe that AR offers a platform to strategise on how to address this challenge. To build capacity, teachers need to begin to understand technology whilst progressing to know how to teach it (Department of Education 2003).

Taking cognisance of the principles of AR, the researchers embarked on preliminary (reconnaissance) AR to confirm the problem that we identified above. They explained their research design. Preliminary research is done to ensure that one does not find out after putting in a lot of effort, that one's idea is not a good one for the study (Hofstee 2006). Baseline data needs to be gathered on prior intervention. Knowing how technology teachers performed before the intervention (that is, at the beginning of this study) gives a starting point for comparing the effectiveness of the intervention - when the researchers will compare the results from the preliminary study with those of the main AR later.

\section{RESEARCH DESIGN FOR THE RECONNAISSANCE}

In line with critical theory explained above, the empirical engagements in the study were guided by a critical paradigm. This paradigm is suited to the critical reflections on technology teachers' incapacity manifested in their limited knowledge of technology and its pedagogy (Mertens 1998) and taking action to resolve this situation. Mertens (1998) claims that emancipatory researchers argue that the constructivist or interpretive researchers "did change the rules but did not change the nature of the game". An emancipatory paradigm criticises interpretive or constructive researchers, claiming that their research still consists of a small group of powerful experts researching a large number of powerless participants (Mertens 1998). Mertens (1998) draws from Reason and Bradbury (2001) that emancipatory paradigm "directly addresses the politics in research by confronting social oppression at whatever level it occurs". Oppression in this study relates to the situation about technology teachers not really knowledgeable with technology - an oppressive situation. Cohen et al. (2000) argue that the intention of researchers of emancipatory paradigm is the emancipation of the individuals and groups in an egalitarian society. The individuals in this study refer to the technology teachers per selected schools at Mankweng Circuit.

This is an action research (AR) study. An AR approach was used during the reconnaissance study. The intention of applying AR in this study was to solve classroom problems through conducting interviews, classroom observation during the delivery of lessons and administering of a questionnaire. It is concerned with a local problem and is conducted in a local setting. The primary goal of AR is to find a solution to a given problem. The value of AR is confined primarily to those conducting it (Gay 1987). The researchers engaged the first stage of ac- 
tion research (reconnaissance study) in the process of identifying the problem. According to Kemmis and McTaggart (1988) reconnaissance is the initial reflection of the research situation in view of the researcher's thematic concern. The researchers engaged secondary school technology teachers of Mankweng District of Limpopo Province in their natural work setting to explore their need areas in conjunction with those that the researchers identified. It was hoped that both the novice and experienced teachers involved in this AR study would be empowered to teach technology irrespective of their contextual setting. The study would contribute significantly to action research studies in the field of technology education.

The researchers identified the province, region, district, circuit, schools and technology teachers to be used for data collection. The sample was drawn from Capricorn Region at Mankweng Circuit of Mankweng District. The choice of Mankweng Circuit was prompted by the lack of technology knowledge observed previously by one of us as stated above.The aim of delineating the scope of the study was to implement some intervention strategies to a manageable sample of technology teachers teaching Grades 8 and 9. Mankweng Circuit was chosen as a cluster sampling strategy. In this cluster sampling groups of Grade 8 and 9 technology teachers were randomly selected (Gay 1987) in terms of their schools.

Cluster samples were drawn from five secondary schools (see Table 1) at Mankweng Circuit. Cluster sampling is characterised by some degree of homogeneity (Maree and Pietersen 2010; McMillan and Schumacher 1989). Though the sampled schools are located in varied milieus (rural and urban), they were all secondary schools. It should also be noted that the researchers' focus was on the technology teach- ers sampled from these schools - a total of eighteen teachers. Pseudo names were assigned to the schools to conceal their true identity.

The selected technology teachers' characteristics included: they all faced some challenges in the teaching of technology; for convenience in organising the groups, the schools were a reasonable distance from one another within one circuit, districts, regions and province; only Grade 8 and 9 technology teachers in the same senior phase were selected; all these teachers taught technology. The total number of the sampled technology teachers is reflected per school in Table 1. Some taught Grade 8 only, some taught Grade 9 only while some taught both grades.

Once the sample had been drawn, the circuit manager's help was sought to inform the schools. He called the headmasters of the identified schools in the researchers' presence, informing them that their schools had been earmarked for participation in technology research and that the researchers would visit their schools shortly. The researchers thus visited the schools to introduce themselves. They were received by the schools' management teams (SMTs) during which they explained the purpose of their visit and that of the study. The technology, mathematics and science education heads of department would convene their technology teachers in their schools.

Data was collected during the first term of 2010. A variety of data collection techniques were incorporated on a small scale as this was only a fact-finding (reconnaissance) study - non-participant observation, structured interviews and qualitative questionnaires (McNiff 1988; Ferrance 2000). According to Wadsworth (cited in Maree 2010), multiple methods help the researcher to overtly seek different kinds of views and perspectives from data sources. Multiple meth-

Table 1: Sampled schools and technology teachers

\begin{tabular}{lccccc}
\hline School name & \multicolumn{3}{c}{ Sampled technology teachers } & School milieu \\
\cline { 2 - 5 } & No. per sch. & Grade 8 & Grade 9 & Both grades \\
\hline KMK High & 7 & 2 & 2 & 3 & None \\
VMV High & 3 & 1 & 2 & 1 & Rural \\
RMR High & 3 & 1 & 1 & None & Rural \\
BMB High & 3 & 1 & 2 & 2 & Rural \\
WHW High & 2 & 2 & 2 & 6 & Urban \\
\hline Total & 18 & 7 & 9 &
\end{tabular}


ods also helped us to overcome the bias that could otherwise result from the use of a single method. Triangulation or integrated results from different data sources enabled us to explain in greater depth the extent of the challenges faced by technology teachers in their teaching of technology from more than one standpoint (Cohen et al. 2000). A day was spent at each school to observe technology teachers giving lessons using the observation grid that was designed by the researchers (AR practitioners). The observation was followed by interviewing the teachers using the interview schedule. The researchers designed both the observation and interview instruments. Finally, teachers were given a questionnaire to fill in.

Permission to conduct the research was requested and granted by Department of Education Limpopo Province. The circuit manager was also duly informed. The teachers were also required to sign consent letters for their participation in the study. Even though learners were not directly involved in the study, we sent consent letters to their parents with the help of teachers. This was because as part of gathering data to assess the extent of the needed intervention, the researchers planned to observe the teaching taking place in class.

Data analysis followed a thematic and narrative form. Themes that emerged from the analysis of the three data types (observations, interviews and questionnaire) guided the presentation of findings. This process of data analysis focused on understanding the teaching and learning actions and events within the participants' settings and contexts. Findings from the observations served as an umbrella for the interviews and questionnaire. Findings from the interviews and questionnaires sought clarity of the observation. Thus, observations were followed by interviews (which were memberchecked after their transcription) and the questionnaire during data gathering. Thus, data from these sources were analyzed holistically.

\section{FINDINGS AND DISCUSSION}

\section{Participants' Biographical Information}

The researchers start by presenting the results from technology teachers' biographical information as captured in Table 2.

There were eighteen participants from the five participating high schools, nine males and nine females. Eleven participants had less than six years of technology teaching experience while seven had more than five years of technology teaching experience and seven had more than six years technology teaching experience. Eleven participants did not have any technology education qualification; seven had some form of that qualification. Thirteen of the participants worked in rural areas whereas five worked in urban areas. Ten participants could plan the technology lessons whereas eight still needed some help.

\section{Findings from Observation, Interviews and Questionnaire}

The themes were selected to cover aspects of technology teaching from policy interpretation to classroom practice. These themes include technology-specific teaching experience, technology lesson planning, technology assessment, level of internal and external support for technology teaching, resources for technology teaching and learning, technology curriculum policy interpretation and implementation, and teacher-learner ratio in a technology class.

\section{Technology-specific Teaching Experience}

Many teachers of technology were asked by Department of Education to volunteer to teach technology. As a result many do not have any qualifications in technology education (Nkosi 2008; Lovington 2009; Potgieter 2004). Some may be experienced in other subjects because they

Table 2: Grade 8 and 9 technology teachers' biographical information

\begin{tabular}{|c|c|c|c|c|c|c|c|c|c|}
\hline \multicolumn{2}{|c|}{ Gender } & \multicolumn{2}{|c|}{$\begin{array}{c}\text { Technology teaching } \\
\text { experience }\end{array}$} & \multicolumn{2}{|c|}{$\begin{array}{l}\text { Technology } \\
\text { qualification }\end{array}$} & \multicolumn{2}{|c|}{ School milieu } & \multicolumn{2}{|c|}{$\begin{array}{c}\text { Can plan } \\
\text { technology lesson }\end{array}$} \\
\hline$M$ & $F$ & $\begin{array}{c}\text { Less than } \\
6 \text { yrs }\end{array}$ & $\begin{array}{l}\text { More than } \\
6 \text { yrs }\end{array}$ & Yes & $N o$ & Rural & Urban & Yes & $\mathrm{No}$ \\
\hline 9 & 9 & 11 & 7 & 7 & 11 & 1 & 6 & 10 & 8 \\
\hline
\end{tabular}


were already qualified in those subjects when they were asked to cross over into technology. Hence, many of them may be qualified in other subjects but not specifically in technology education. Given this background, and the findings from the teachers' biographical information in Table 2, they held reasons for teaching technology which ranged from being coerced into teaching it to basically having the passion for it. For instance, the interviews revealed two teachers stating:

It was just allocated to me.

It's fun, interesting and compels one to be innovative.

Bearing in mind this situation, most of technology teachers are generally uncomfortable with the pedagogy of technology as it was observed and revealed from the interviews. Some did not even have any interest in teaching technology as one contended:

It just came along while I am already teaching and I didn't develop any interest in the subject.

It can be gathered from the teachers' responses, that they were not grounded in technology subject. By implication this suggests that they had challenges planning the technology lessons.

\section{Technology Lesson Planning}

Teachers' responses in the questionnaire revealed that only seven out of eighteen teachers indicated the importance of using both the textbook and the curriculum policy document for their lesson planning. However, it surfaced from the interviews that teachers prioritised the use of a textbook as some indicated:

If educators were provided with at least a textbook so that we are able to prepare our learning programme. I don't think the challenges I meet as stated would have happened if I had relevant and enough textbooks for learners. We need enough textbooks and learner support material.

It would appear that teachers expected to be given a ready-made lesson plan so that they get in class and teach, without having to start by working hard developing lesson plans:

We want to be supplied with pacesetters, scheme of work and draft lesson plans.

This was confirmed when we requested teachers' lesson plans so that we could follow their teaching properly during the observations. Many could not produce them. This could only mean two things: either they did not prepare any lesson plans, or they were uncomfortable to disclose them to us out of lack of confidence that they planned correctly. Only two teachers out of five schools could show us their lesson plans.

\section{Technology Assessment}

Assessment should ideally be integrated with planning so that teaching and learning activities are not devoid of it (Motshekga 2009). An interview question sought to establish the assessment methods that technology teachers applied during their teaching. One teacher responded by not really giving the answer that we sought in this regard:

We are assessing skills, knowledge, attitude and values. We evaluate learners' performance.

However, some of the teachers mentioned the assessment strategies that they applied in their technology class - assignments, class work, homework, tests and examinations. In the questionnaire teachers were asked to indicate if they planned any technology design projects or any tasks (capability, case study or resource tasks) for their learners. They did not check this aspect in the questionnaire. One teacher blamed lack of support by the school on this matter:

Technology at our school is not taken into consideration because learners are not doing any practical work.

This is quite unfortunate because teaching of technology mainly follows a design project approach in the context of problem solving. Only three teachers indicated in the interviews that they had a copy of provincial or national assessment manuals. This confirms their lack of capacity in terms of assessment in technology.

\section{Level of Internal and External Support}

Technology, being relatively new in the curriculum, may not thrive without a concerted commitment to empowering teachers. Teachers were keen to see support both from within and outside their schools to help them develop in the knowledge and teaching of technology. They expressed this need as follows during the interviews: 
The principal should develop interest in technology education so that he cannot have a problem in allocating a budget for technology education. Mentors will be highly appreciated to visit the school regularly. Parents should take part also.

The teachers urged their School Management Teams to take technology seriously and to allocate its budget and teachers accordingly. The responses from the questionnaire indicated that support received from district office was very weak compared to support received from their colleagues and School Management Teams. The expressed lack of support from the district was attributed to the fact that the district had not yet appointed a district-based subject advisor for technology education.

Lack of support was also experienced in terms of provision of resources as can be seen from the next set of findings.

\section{Resources for Technology Teaching and Learning}

It was observed that there was a lack of textbooks for both teachers and learners. In some schools there was not more than one textbook among the learners. Some teachers in the same schools were sharing a textbook. This state of affairs was confirmed from the findings from the interviews as expressed by respondents:

We don't have enough resources. I guess technology is a hands-on subject, but there are no resources available. Learners should be encouraged to buy necessary resources if needed.

The teachers sampled pleaded for Department of Education Limpopo Province and their schools to provide the necessary resources resources for learner group projects, a workshop centre where learners can do technology handson, technology materials to expose and orientate learners on, and a technology resource centre.

The researchers observed, in all the selected schools, that were no technology-specific rooms where learners could engage in practical and making activities or projects.

Technology curriculum policy interpretation and implementation

It was evident from all data sources that there was a great need for teachers to have access to the technology curriculum document in the first place, and to be helped to interpret and implement it. One teacher remarked in this regard:

I don't think the challenges I meet as stated would have happened should I have had the technology curriculum policy document as a guide.

The researchers requested the teachers to show us the curriculum policy documents that they were using. No one had any across all the sampled schools. A few of them offered the excuse that they had the documents but could not locate them at that stage. A few responses in the interviews on this aspect, which were confirmed by how the teachers responded to the questionnaire, were that they did not have them; that even if they had them they could not interpret or implement them. Here are the accounts of three of them:

I don't know the learning outcomes. We don't have the policy documents at our school. I don't know the learning outcomes by heart; I have to refer to the curriculum policy document.

\section{Teacher-learner Ratio in a Technology Class}

Unmanageable learner numbers in a technology class render the teaching of technology ineffective (Ankiewicz et al. 2003). This becomes an added constraint that technology teachers are faced with. The researchers observed that teachers' movement in the classroom during their lessons, and their interaction with learners was extremely limited due to overcrowding. It was difficult to have a chair or even a space to sit down. The teacher-learner ratio ranged from 1:60 to 1:90. This proved to impact on a few things, for example even though the schools had a monthly schedule for tests, the interview findings indicated that the turnaround time for marking learners' written tests took between two and three weeks. Marking overlapped into the next test dates. One teacher expressed his concern in this regard:

The department needs to improve the teacher-learner ratio so that an educator is faced with a manageable class.

\section{CONCLUSION}

This study set out to identify the gaps that Grade 8 and 9 technology teachers at Mankweng Circuit of Limpopo Province faced regard- 
ing their knowledge and teaching of technology. A reconnaissance study as part of AR was employed to achieve this goal. The researchers identified the problem as it unfolded. They entered the study holding certain assumptions surrounding the problem. But since this was an AR study, the researchers embarked on the reconnaissance study to verify our problem and assumptions. The findings from the reconnaissance study confirmed the problem as identified. There was a definite problem regarding the interpretation of the technology curriculum policy document, programme, schedule and lesson planning, and failure to take advantage of the available resources. This problem was magnified by other related problems that were revealed by the findings, for instance, lack of internal and external support and what seemed an unmanageable teacher-learner ratio.

\section{RECOMMENDATIONS}

The findings of this study suggest that certain recommendations be made:

- The challenges that technology teachers face need intervention. For us researchers we plan to respond to these challenges in the near future by embarking on AR study.

- Given the extent of the challenges that these teachers face, Department of Education should consider giving special attention to the training of technology teachers in Limpopo Province. That some of these teachers could not even plan a technology lesson spells out the magnitude of the problem.

- Whilst teachers can be made aware of the creative ways to use available resources, Department of Education should make an effort to resources schools for the effective way to teach technology. A budget should be considered to design and build techno-labs in schools.

- Whilst teachers can be helped to think of creative ways to teach technology to crowded classes, overcrowding in itself should be seen as a constraint and Department of Education should address it.

\section{REFERENCES}

Ankiewicz P, De Swardt E, Gross E, Reddy V 2003. The essential features of technology and technology education: A conceptual framework for the development of OBE related programmes in technology education. International Journal of Technology and Design Education, 13(27): 45.

Bradbury H, Reason P 2001. The SAGE Handbook of Action Research: Participative Inquiry and Prac-

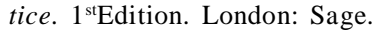

Chisholm L, Mahomed H, Ndlovu T, Potenza E, Volmink J et al. 2000. A South African Curriculum for the $21^{\text {st }}$ Century: Report of the Review Committee on Curriculum 2005 1-100. Pretoria: Government Printer.

Cohen L, Manion L, Morrison K 2000. Research Methods in Education. London: Routledge.

Creswell JW 1994. Research Design: Qualitative and Quantitative Approaches. Thousand Oaks: Sage.

Christensen L, Johnson B 2004. Educational Research: Quantitative, Qualitative and Mixed Approaches. $2^{\text {nd }}$ Edition. Boston: Pearson.

De Jager R 2011. Latest Changes in the Technology Education Curriculum in South Africa. Paper Presented at PATT25: CRIPT 8 Conference in June in London.

Department of Education 2001. Policy Document: Technology Intervention, Curriculum 2005 Grades 5 and 9. Pretoria: Government Printers.

Department of Education 2003. Revised National Curriculum Statement Grades $R-9$ (Schools): Teacher's Guide for Developing Learning Programmes Technology. Pretoria: Government Printers.

Department of Education 2004. Revised National Curriculum Statement Grades 7-9 (Schools). Pretoria: Government Printers.

De Vos AS, Delport LSL, Fouche CS, Strydom H 2002. Research at Grass Roots. $2^{\text {nd }}$ Edition. Pretoria: Van Schaik.

Ferrance E 2000. Action Research. Virgin Island: Brown University.

Gay LR 1987. Educational Research: Competencies for Analysis and Application. $3^{\text {rd }}$ Edition. Columbus: Merrill.

Hofstee E 2006. Constructing a Good Dissertation: A Practical Guide to Finishing a Master's, MBA or PhD on Schedule. Sandton: EPE.

Kemmis S, McTaggart R 1988. The Action Research Planner. Victoria: Deakin University.

Letsoalo MR 2007. The Need for an Instrument to Monitor Technology Process Puring Technology Projects. BEd (Hons) Treatise. University of Limpopo, Polokwane.

Lovington DS 2009. Problems Experienced by Educators in the Training of Technology at Etwatwa Schools. From <http://152.106.200:8080/dspace/ handle/10210/2013> (Retrieved February 29, 2012).

Maree K, Pietersen J 2010. Sampling. In: K Maree (Ed.): First Steps in Research. Pretoria: Van Schaik, pp. 176-129.

Mauer KE 1996. Formulating Proposal for Theoretical and Qualitative Research. Johannesburg: RAU Press.

McMillan JH, Schumacher S 1989. Research in Education: A Conceptual Introduction. $2^{\text {nd }}$ Edition. London: Harper Collins. 
McNiff J 1988. Action Research: Principles and Practice. New York: Macmillan Education Ltd.

Mertens DM 1998. Research in Education and Psychology. London: Sage Publications.

Motshekga A 2009. Report of the Task Team for the Review of the Implementation of the National Curriculum Statement. Statement by Minister of Basic Education on CurriculumReview Final Report. Pretoria: Government Printers.

Nkosi DF 2008. Technological Process as a Framework for the Improvement of Instruction of Technology. MEd Dissertation. University of Johannesburg, Johannesburg.

Potgieter C 2004. The impact of technology education, as a new learning area, on in-service teacher education in South Africa. International Journal of Technology and Design Education, 14: 205-218.

Pretorius JP 2004. Not Enough Spent on Skills Development. Many Teachers Still Missing Out on Training. This Day, Weekly, February, 19, 2004, P. 7.

Pudi TI 2007. Understanding Technology Education from South African Perspective. Pretoria: Van Schaik.

Rauscher W 2010. The technological knowledge used by technology education students in capability tasks. International Journal of Technology and Design Education, 21: 291-305.

Reddy K 2001. The Education of Pre-service Teachers in Technology Education. PhD Thesis, Unpublished. Johannesburg: Rand Afrikaans University.

Schafër M 1999. Designing and Making a Difference: An Exploration of Technology Education for Rural School Teachers. MEd Dissertation. Cape Town: Rhodes University.

Tooley WR 2000. Political Rationality and Government Mechanisms: Maori Education Policy in the New Millennium. MA in Education Dissertation. University of Auckland, Auckland.

Watson SL, Watson WR 2011. Critical, emancipatory, and pluralistic research for education: A review of critical systems theory. Journal of Thought, FallWinter: 63-77.

Williamson T 2013. Emancipatory Politics, Emancipatory Political Science: On Erik Olin Wright's Envisioning Real Utopias. Engaging Emancipatory Social Science and Social Theory: A Symposium on Erik Olin Wright's Envisioning Real Utopias. From <http://www.tandfonline.com/loi/cnps20> (Retrieved April 23, 2013). 